\title{
Effect of gamma irradiation on the nutritional quality of Agaricus bisporus strains cultivated in different composts
}

\author{
MEIRE C.N. ANDRADE ${ }^{1}$, JOÃO P.F. JESUS ${ }^{2}$, FABRÍCIO R. VIEIRA ${ }^{2}$, \\ STHEFANY R.F. VIANA ${ }^{2}$, MARTA H.F. SPOTO ${ }^{3}$ and MARLI T.A. MINHONI ${ }^{2}$ \\ ${ }^{1}$ Universidade do Sagrado Coração/USC, Centro de Ciências Exatas e Sociais Aplicadas, \\ Rua Irmã Arminda, 10-50, Jardim Brasil, 17011-160 Bauru, SP, Brasil \\ ${ }^{2}$ Universidade Estadual Paulista/UNESP, Faculdade de Ciências Agronômicas/FCA, \\ Departamento de Produção Vegetal/Defesa Fitossanitária, Módulo de Cogumelos, \\ Rua José Barbosa de Barros, 1780, Fazenda Lageado, Caixa Postal 237, 18610-307 Botucatu, SP, Brasil \\ ${ }^{3}$ Universidade de São Paulo/USP, Escola Superior de Agricultura “Luiz de Queiroz"/ESALQ, Departamento de Agroindústria, \\ Alimentos e Nutrição, Av. Pádua Dias, 11, Caixa Postal 9, 13418-900 Piracicaba, SP, Brasil \\ Manuscript received on August 1, 2012; accepted for publication on May 13, 2013
}

\begin{abstract}
The effect of irradiation doses $(0,125,250$ and $500 \mathrm{~Gy})$ on the nutritional quality of $A$. bisporus mushrooms (strains ABI-07/06, ABI-05/03 and PB-1) cultivated in composts based on oat straw (Avena sativa) and brachiaria (Brachiaria sp.) was evaluated. The experimental design was $4 \times 3 \times 2$ factorial scheme (irradiation doses $\mathrm{x}$ strains $\mathrm{x}$ composts), with 24 treatments, consisting of two repetitions each, totaling 48 experimental units (samples of mushrooms). The samples were irradiated in Cobalt-60 irradiator, model Gammacell $220 \mathrm{kGy}$, with dose rate of $0.740 \mathrm{kGy} \mathrm{h}^{-1}$, according to the treatments proposed. Subsequently, the control (unirradiated) and the other treatments were maintained at $4 \pm 1^{\circ} \mathrm{C}$ and $90 \% \mathrm{RH}$ in a climatic chamber for carrying out the chemical analysis of the mushrooms on the $1^{\text {st }}$ and $14^{\text {th }}$ day of storage. It was found that all $A$. bisporus strains evaluated were food with excellent nutritional value, because they presented high protein and fiber contents and low ethereal extract content; the chemical characterization of the mushrooms was influenced by the compost type in which they were cultivated; gamma irradiation influenced the chemical composition of mushrooms.
\end{abstract}

Key words: Agaricus bisporus, productivity, strains, compost, nutritional value.

\section{INTRODUCTION}

Edible fungi are food with high nutritional values (Bononi et al. 1995). However, their shelf life, as well as their nutritional value, vary according to the species, strain, processing after harvest, development stage of the mushroom, part of the mushroom (cap or stem) and the type of cultivation substrate used (Andrade et al. 2008, Minhoni et al. 2005).

Correspondence to: Meire Cristina Nogueira de Andrade

E-mail:mcnandrade@hotmail.com
Despite its importance and use in human feeding, little is known in Brazil about the quality of edible mushrooms. Trays with fresh mushrooms containing questionable nutritional information are usually found in the market, since the sources consulted are not always cited (Andrade et al. 2008). Information regarding the food composition, such as protein, fat and fiber contents, has become very important for food and health professionals. The consumer also seems to be in search of natural 
sources of vitamins and shown interest in good quality products (Furlani 2004).

Preservative solutions associated to cooling have already been successfully tested for the conservation of $A$. bisporus. Citric acid and the hydrogen peroxide (as acidifying agent and a preservative in low concentrations), calcium hypochlorite and calcium chloride, sorbitol, sodium erisorbate cysteine and glucan-delta-lactone have already been used to treat fresh mushrooms with satisfactory results (Brennan et al. 2000, Kuyper et al. 1993). However, it is known that these solutions break down the original taste of fresh mushrooms and that mushrooms are subjected to changes, including their nutritive value.

To maintain the physical and chemical characteristics of fresh A. bisporus mushroom, gamma irradiation has been used in many countries. However, this technique has seldom been used in Brazil for edible mushrooms. Among the most recent researches conducted in Brazil, Moda (2008) evaluated the shelf life of fresh Pleurotus sajor-caju irradiated with 125, 250, 500 and 750 Gy and found that the dose of 750 Gy was optimal. However, there are no scientific reports in Brazil about the use of gamma irradiation for $A$. bisporus.

Thus, the object of the present study was to evaluate the effect of gamma irradiation on the nutritional quality of Agaricus bisporus mushrooms produced in different composts.

\section{MATERIALS AND METHODS}

The mushroom production was carried out at the Mushroom Module facilities, Department of Plant Production, School of Agricultural Sciences (FCA/ UNESP), Botucatu, São Paulo, Brazil.

\section{EXPERIMENTAL DESIGN AND TREATMENTS}

The experimental design was a $4 \times 3 \times 2$ factorial scheme (irradiation doses $\mathrm{x}$ strains $\mathrm{x}$ composts), with 24 treatments, each consisting of two repetitions, totaling 48 experimental units (samples of mushrooms). The data were submitted to ANOVA and averages were compared by Tukey test at $5 \%$, by using the software SISVAR 4.2 statistical program, developed by the Department of Mathematical Sciences from the UFLA (Federal University of Lavras), Minas Gerais, Brazil.

\section{AGARICUS BISPORUS STRAINS}

Pure cultures (primary matrix) of strains ABI07/06, ABI-05/03 and PB-1 were used, of which strain ABI-07/06 originated from Piedade-SP, strain ABI-05/03 from Cabreúva-SP and strain PB-1 from the Brasmicel mycelium company in Suzano-SP (according to the log files of the company, strain PB-1 was obtained from Paul Stamets, from Washington, USA, in the year 2000). The strains were maintained in stock culture based on CA (compost agar) culture medium, immersed in sterilized mineral oil and conserved in BOD adjusted to $8^{\circ} \mathrm{C}$, stored in the Mushrooms Module Mycology Collection, located at the Department of Plant Production of School of Agronomic Sciences, UNESP, Botucatu, São Paulo, Brazil.

\section{COMPOSTING, GROWING AND HARVESTING}

Two types of composts based on brachiaria (Brachiaria sp.) straw and oat (Avena sativa) straw were formulated, with an initial $\mathrm{C} / \mathrm{N}$ ratio of approximately 25/1, for the cultivation of $A$. bisporus strains. All phases of composting, growing and harvesting followed the procedures used by Andrade et al. (2008).

POST-HARVEST

The mushrooms collected from all culture conditions proposed, were stored in plastic bags containing $200 \mathrm{~g}$. The transportation of the samples to the Center for Nuclear Energy in Agriculture (CENA), University of São Paulo (USP), was performed in isothermal boxes, which were irradiated with 125 , 250 and 500 Gy in a Cobalt-60 irradiator, model Gammacell 220, with dose rate of $0.740 \mathrm{kGy} \mathrm{h}^{-1}$. 
The control (unirradiated) and the other treatments were kept at $4 \pm 1^{\circ} \mathrm{C}$ and $90 \%$ in a climatic chamber to carry out the physical-chemical analyses on the $1^{\text {st }}$ and $14^{\text {th }}$ day of storage.

\section{VARIABLES ANALYZED}

Crude protein, ethereal extract, crude fiber and ash contents of the mushrooms obtained from the proposed treatments were evaluated. The Weende method, described by Silva and Queiroz (2002), was used for analyses.
The evaluations were made in two periods ( $1^{\text {st }}$ and $14^{\text {th }}$ day of storage), with 48 samples in each period, totaling 96 samples at the end of the experiment.

\section{RESULTS AND DISCUSSION}

The $\mathrm{F}$ values of ash, crude fiber, ethereal extract and crude protein contents of $A$. bisporus mushrooms on the $1^{\text {st }}$ day of storage are shown in Table I.

In the compost based on oat straw, on the $1^{\text {st }}$ day of storage, the ABI-05/03 strain had the

TABLE I

F values obtained from the analysis of variance of ash, crude fiber, ethereal extract and crude protein in the Agaricus bisporus strains ABI-05/03, ABI-07/06 and PB-1, on the $1^{\text {st }}$ day of storage, cultivated in two types of composts based on oat straw (Avena sativa) and brachiaria (Brachiaria sp.) and submitted to irradiation doses 0, 125, 250 and $500 \mathrm{~Gy}$.

\begin{tabular}{ccccc}
\hline Cause of variation & Ash & Crude fiber & Ethereal extract & Crude protein \\
\hline Strain (S) & $76.7^{* *}$ & $24.7^{* *}$ & $0.1 \mathrm{~ns}$ & $44.2^{* *}$ \\
Types of composts (C) & $3.7 \mathrm{~ns}$ & $0.1 \mathrm{~ns}$ & $4.3^{*}$ & $5.2^{*}$ \\
Irradiation dose (D) & $12.8^{* *}$ & $10^{* *}$ & $1.2 \mathrm{~ns}$ & $3.0^{*}$ \\
S x C & $16.9^{* *}$ & $0.1 \mathrm{~ns}$ & $1.1 \mathrm{~ns}$ & $1.4 \mathrm{~ns}$ \\
S x D & $5.4 * *$ & $0.5 \mathrm{~ns}$ & $0.4 \mathrm{~ns}$ & $0.6 \mathrm{~ns}$ \\
C x D & $1.6 \mathrm{~ns}$ & $0.5 \mathrm{~ns}$ & $0.1 \mathrm{~ns}$ & $0.7 \mathrm{~ns}$ \\
S x C x D & $2.4 \mathrm{~ns}$ & $0.9 \mathrm{~ns}$ & $0.5 \mathrm{~ns}$ & $0.9 \mathrm{~ns}$ \\
CV, $\%$ & 3.66 & 8.64 & 27.53 & 4.54 \\
\hline
\end{tabular}

**Significant at the level of $1 \%$; *significant at the level of $5 \%$; ns= not significant.

highest ash average (16.6\%) and the compost based on brachiaria, ABI-07/06 and ABI-05/03 strains had the highest ash averages (16.6 and 16\%, respectively) (Figure 1). These values are higher than those obtained by Chang and Miles (1989) and Furlani and Godoy (2007), who obtained an average of $12 \%$ of ash for $A$. bisporus.

By comparing the ash content of $A$. bisporus strains when cultivated in the different composts (Figure 1), it was found that ABI-07/06 was the only strain to present statistically different averages. It obtained higher average when cultivated in the compost based on brachiaria (16.6\%) than when cultivated in the compost based on oat (14.9\%). The results were better than the ones obtained by Furlani and Godoy (2007) (12\%) and the interval mentioned by Chang and Miles (1989) (7.7 - 12\%).
In relation to the ash content in each dose of irradiation (Figure 2), it was found that the PB-1 strain had the lowest ash content, when compared to the others (Figure 2). However, there was no influence of irradiation dose in the averages for that strain. Moda (2008), evaluating the increase of shelf-life of fresh Pleurotus sajor-caju mushroom with application of gamma irradiation, also found that the irradiation with different doses $(0,125,250$, 500 and $750 \mathrm{~Gy}$ ) did not change the ash content among the treatments.

The crude fiber content of ABI-05/03 and ABI-07/06 strains were higher than those of PB-1 (Figure 3). Differences in chemical characteristics between fungal strains have already been reported (Andrade et al. 2008). Shibata and Demiate (2003) evaluated the chemical composition of the 


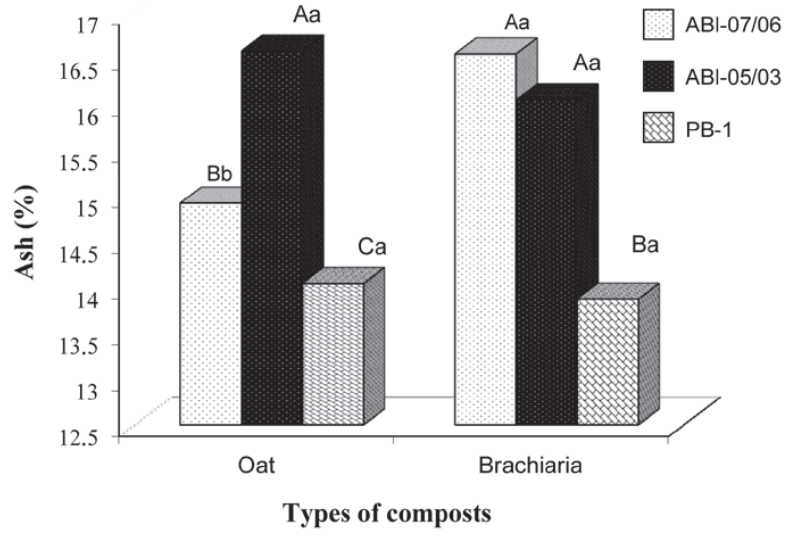

Figure 1 - Comparison of average ash present in the mushrooms on the $1^{\text {st }}$ day of storage according to the Agaricus bisporus strain and the type of compost. Averages followed by same uppercase letters within each compost and lowercase letters within each strain are not statistically different from each other (Tukey, 5\%).

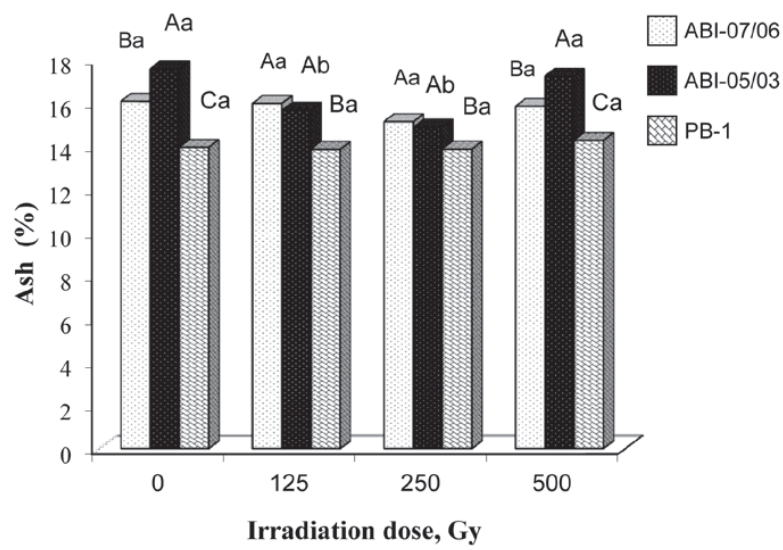

Figure 2 - Comparison of average ash present in mushrooms on $1^{\text {st }}$ day of storage, according to the Agaricus bisporus strains and the irradiation dose. Averages followed by same uppercase letters within each irradiation dose and lowercase letters within each strain are not statistically different from each other (Tukey, $5 \%$ ).

mushroom Agaricus blazei and concluded that there are nutritional differences between the two A. blazei strains tested, in which strain AbM was richer in fibers and minerals, while Jun-17 strain showed a higher carbohydrate content.

Regarding the effect of irradiation, it was found that the highest dose tested (500 Gy) provided the highest average of crude fiber for A. bisporus on the $1^{\text {st }}$ day of storage (Figure 4$)$. Different results

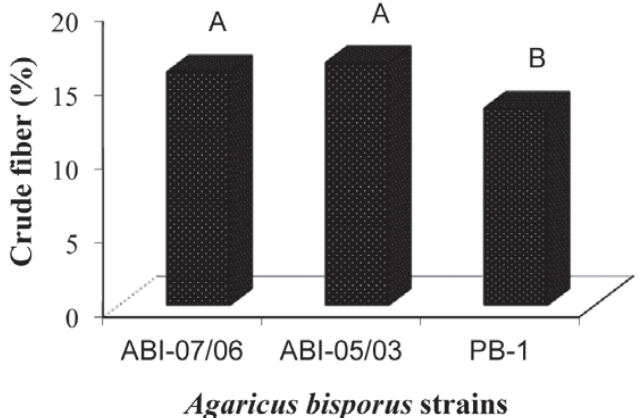

Figure 3 - Comparison of average crude fiber present in mushrooms on the $1^{\text {st }}$ day of storage, according to the Agaricus bisporus strain. Averages followed by same letters are not statistically different from each other (Tukey, 5\%).

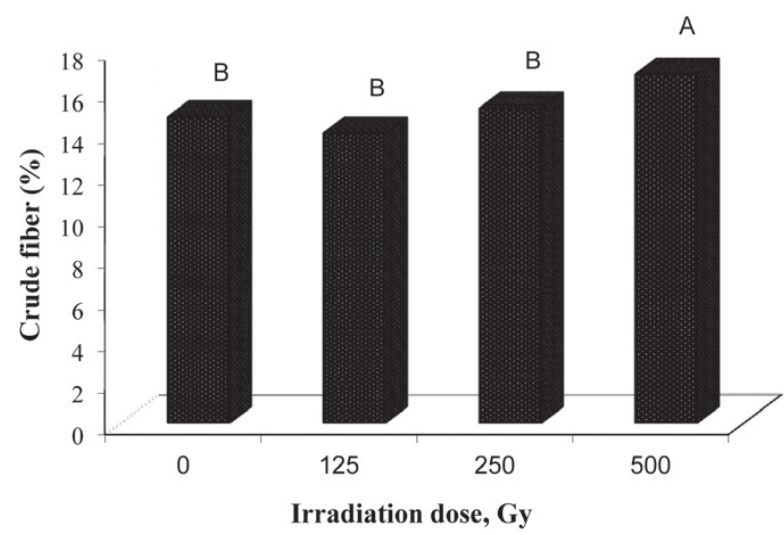

Figure 4 - Comparison of average crude fiber present in mushrooms on the $1^{\text {st }}$ day of storage, according to the irradiation dose. Averages followed by same letters are not statistically different from each other (Tukey, 5\%).

were obtained by Moda (2008) with P. sajor-caju, whose average crude fiber was not influenced by the irradiation dose on the $1^{\text {st }}$ day of storage.

The ethereal extract content of A. bisporus was considered low (1.7 and $1.5 \%$ respectively) when grown on both composts (brachiaria and oat), even though they are different from each other (Figure 5), which is a desirable result in the formation of the mushrooms. Similar results of 1.8 and $1.9 \%$, respectively, were also found by Chang and Miles (1989) and Cheung (1996). However, those data were different from the $5.4 \%$ obtained by Furlani and Godoy (2007). This difference in the results between authors was possibly due to the origin of the mushrooms, regarding the type of the 


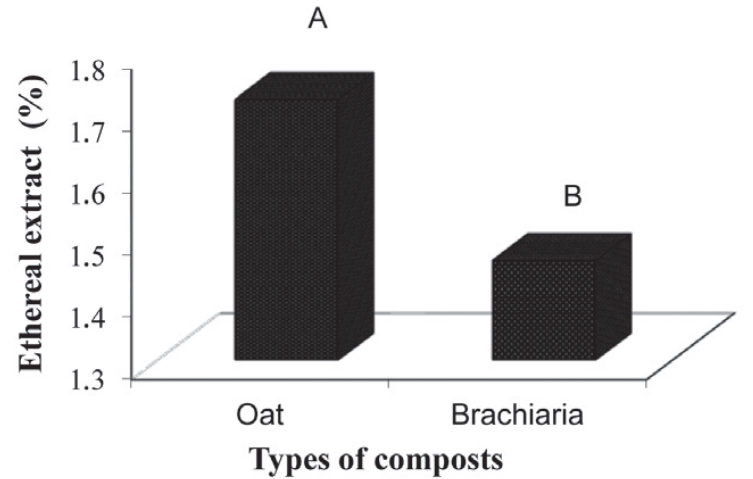

Figure 5 - Comparison of average ethereal extract present in mushrooms on the $1^{\text {st }}$ day of storage, according to the type of compost. Averages followed by different letters are statistically different from each other (Tukey, 5\%).

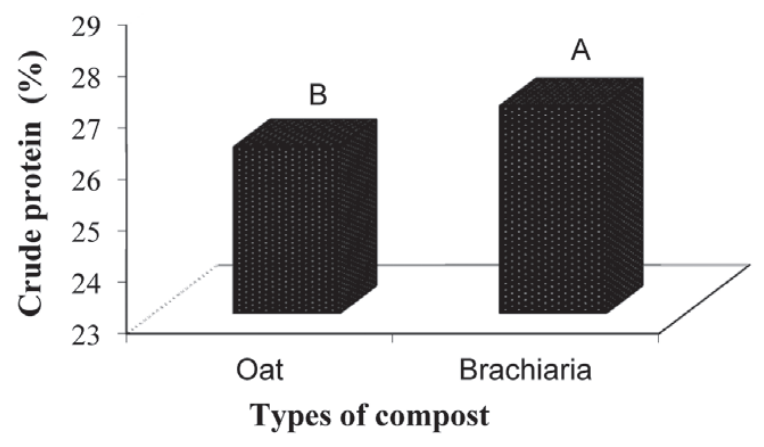

Figure 6 - Comparison of average crude protein present in mushrooms on the $1^{\text {st }}$ day of storage, according to the type of compost. Averages followed by different letters are statistically different from each other (Tukey, 5\%).

strain cultivated and compost used, as reported by Andrade et al. (2008).

In relation to the crude protein content, the compost based on brachiaria obtained the highest averages (Figure 6). PB-1 had the highest average of crude protein (28.9\%) (Figure 7) among the $A$. bisporus strains evaluated. Similar results were obtained by Furlani and Godoy (2007) (28.5\%), Chang and Miles (1989) (26.3\%) and Cheung (1996) (26.8\%).

There was effect of irradiation on the crude protein content of the mushrooms (Figure 8), and the dose of 500 Gy provided the highest average (27.5\%), when compared to those of the control group (26.1\%). Different results were obtained by Moda

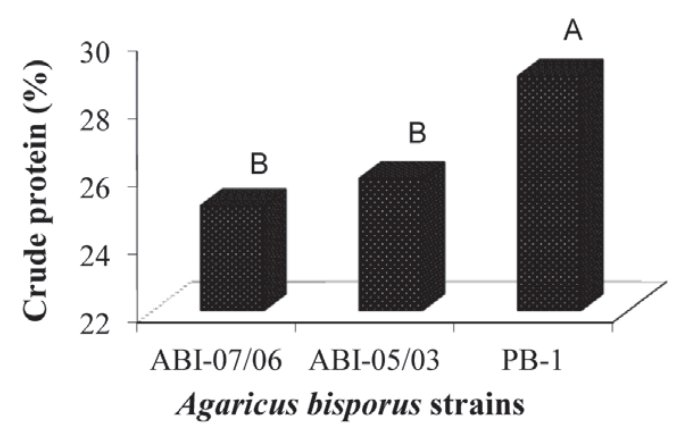

Figure 7 - Comparison of average crude protein present in mushrooms on the $1^{\text {st }}$ day of storage, according to the Agaricus bisporus strain. Averages followed by same letters are not statistically different from each other (Tukey, 5\%).

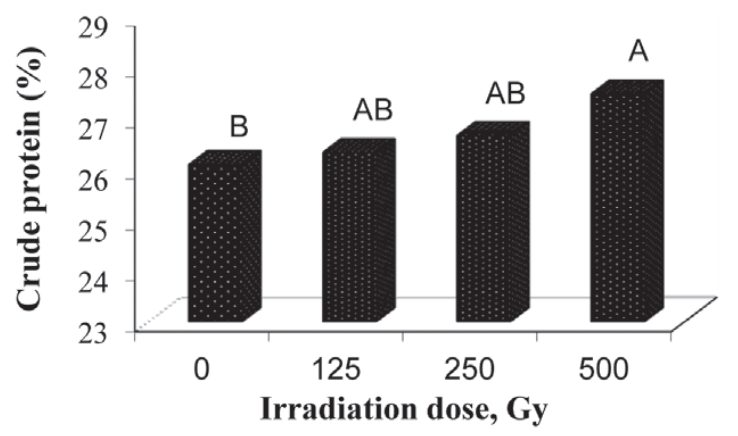

Figure 8 - Comparison of average crude protein present in mushrooms on $1^{\text {st }}$ day of storage, according to the irradiation dose. Averages followed by same letters are not statistically different from each other (Tukey, 5\%).

(2008), who found that irradiation did not affect the crude protein content of Pleurotus sajor-caju.

The $\mathrm{F}$ values of ash, crude fiber, ethereal extract and crude protein contents of $A$. bisporus mushrooms on the $14^{\text {th }}$ day of storage are shown in Table II.

ABI-07/06 and ABI-05/03 strains had higher averages of crude fiber than PB- 1 on the $14^{\text {th }}$ day of storage (Figure 9), similar to what occurred on $1^{\text {st }}$ day of storage (Figure 3). Similar results were also reported by Andrade et al. (2008), who reported that crude protein, ash, and crude fiber contents in the mushroom varied with $A$. bisporus strain and the type of straw used in the compost formulation, when analyzing the cultivation of four A. bisporus strains in three formulations. 
It was found that there was no significant difference in the averages of ethereal extract content on the $14^{\text {th }}$ day of storage for most of the experimental conditions for mushrooms cultivated in both oat and braquiaria composts, submitted or not to the irradiation doses (Figures 10, 11 and 12).

\section{TABLE II}

$F$ values obtained from the analysis of variance of ash, crude fiber, ether extract and crude protein in strains ABI-05/03, ABI-07/06 and PB-1 of Agaricus bisporus mushrooms, stored at $4 \pm 1^{\circ} \mathrm{C}$ for 14 days, cultivated in two types of composts based on oat straw and brachiaria and submitted to irradiation doses of $0,125,250$ and $500 \mathrm{~Gy}$.

\begin{tabular}{ccccc}
\hline Cause of variation & Ash & $\begin{array}{c}\text { Crude } \\
\text { fiber }\end{array}$ & $\begin{array}{c}\text { Ethereal } \\
\text { extract }\end{array}$ & $\begin{array}{c}\text { Crude } \\
\text { Protein }\end{array}$ \\
\hline Strain (S) & $1.7 \mathrm{~ns}$ & $0.01 \mathrm{~ns}$ & $11.8^{* *}$ & $7.7^{* *}$ \\
Compost (C) & $1.3 \mathrm{~ns}$ & $4.3^{*}$ & $10.4^{* *}$ & $4.1 \mathrm{~ns}$ \\
Irradiation dose (D) & $0.9 \mathrm{~ns}$ & $2.2 \mathrm{~ns}$ & $0.8 \mathrm{~ns}$ & $0.7 \mathrm{~ns}$ \\
S x C & $1.0 \mathrm{~ns}$ & $0.4 \mathrm{~ns}$ & $1.1 \mathrm{~ns}$ & $1.3 \mathrm{~ns}$ \\
S x D & $1.0 \mathrm{~ns}$ & $0.5 \mathrm{~ns}$ & $0.5 \mathrm{~ns}$ & $0.4 \mathrm{~ns}$ \\
C x D & $1.0 \mathrm{~ns}$ & $0.4 \mathrm{~ns}$ & $0.8 \mathrm{~ns}$ & $0.4 \mathrm{~ns}$ \\
S x C x D & $0.9 \mathrm{~ns}$ & $0.5 \mathrm{~ns}$ & $2.8^{*}$ & $0.6 \mathrm{~ns}$ \\
CV, \% & 93.0 & 13.4 & 21.4 & 10.4 \\
\hline
\end{tabular}

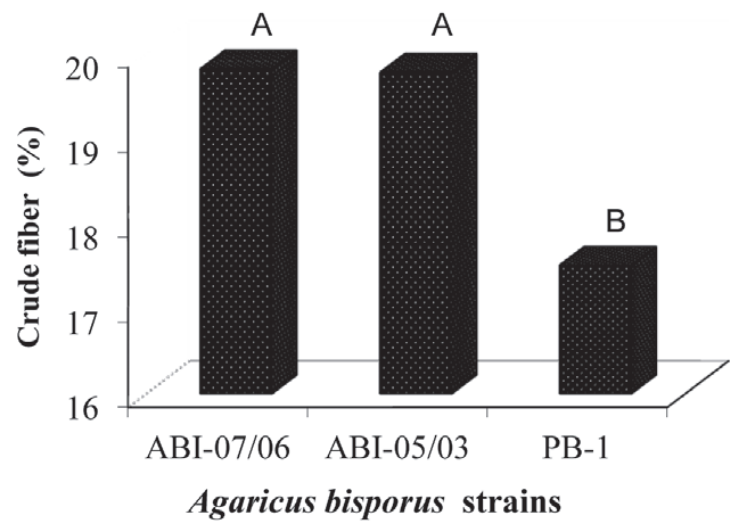

Figure 9 - Comparison of average crude fiber present in mushrooms stored at $4 \pm 1^{\circ} \mathrm{C}$ for 14 days, according to the Agaricus bisporus strain. Averages followed by same letters are not statistically different from each other (Tukey, 5\%).

The averages of ethereal extract ranged from 0.95 to $2.45 \%$, lower values than those found by Furlani and Godoy (2007), who obtained average values of $5 \%$, and similar to those obtained by Cheung (1996), who averaged 1.9\%, and Andrade et al. (2008), who obtained averages ranging from 1.9 to $2.9 \%$.

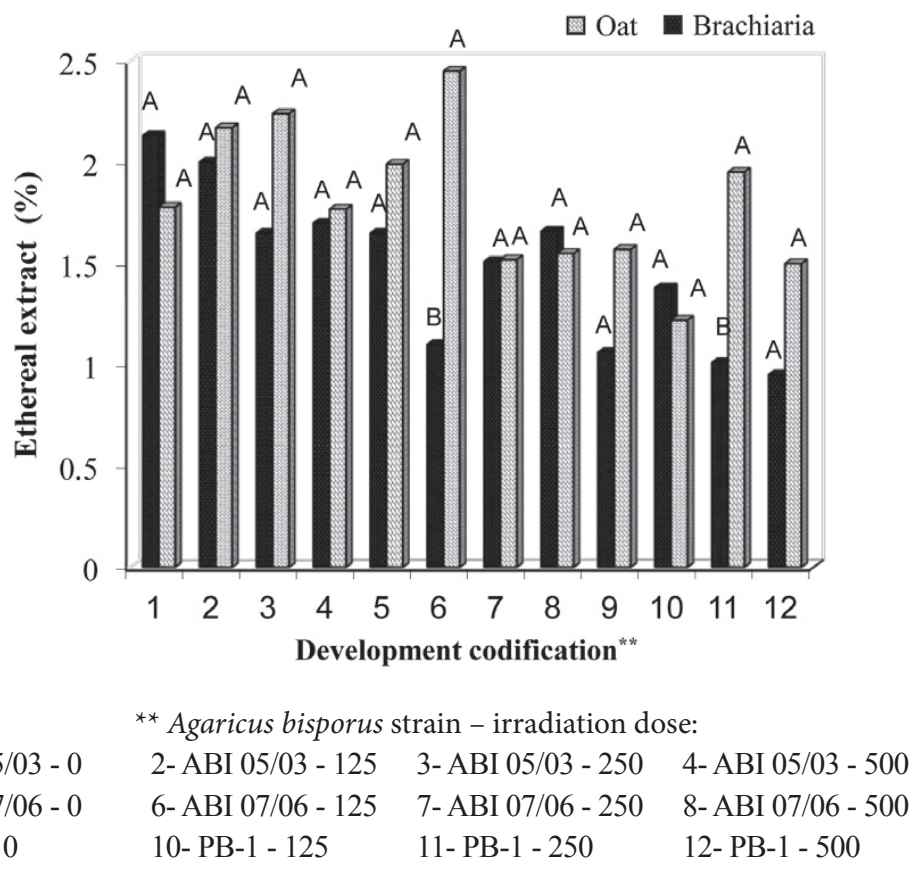

Figure 10 - Comparison of average ethereal extract in mushrooms stored at $4 \pm 1{ }^{\circ} \mathrm{C}$ for 14 days, according to the type of compost. Averages followed by same letters within each codification are not statistically different from each other (Tukey, 5\%). 


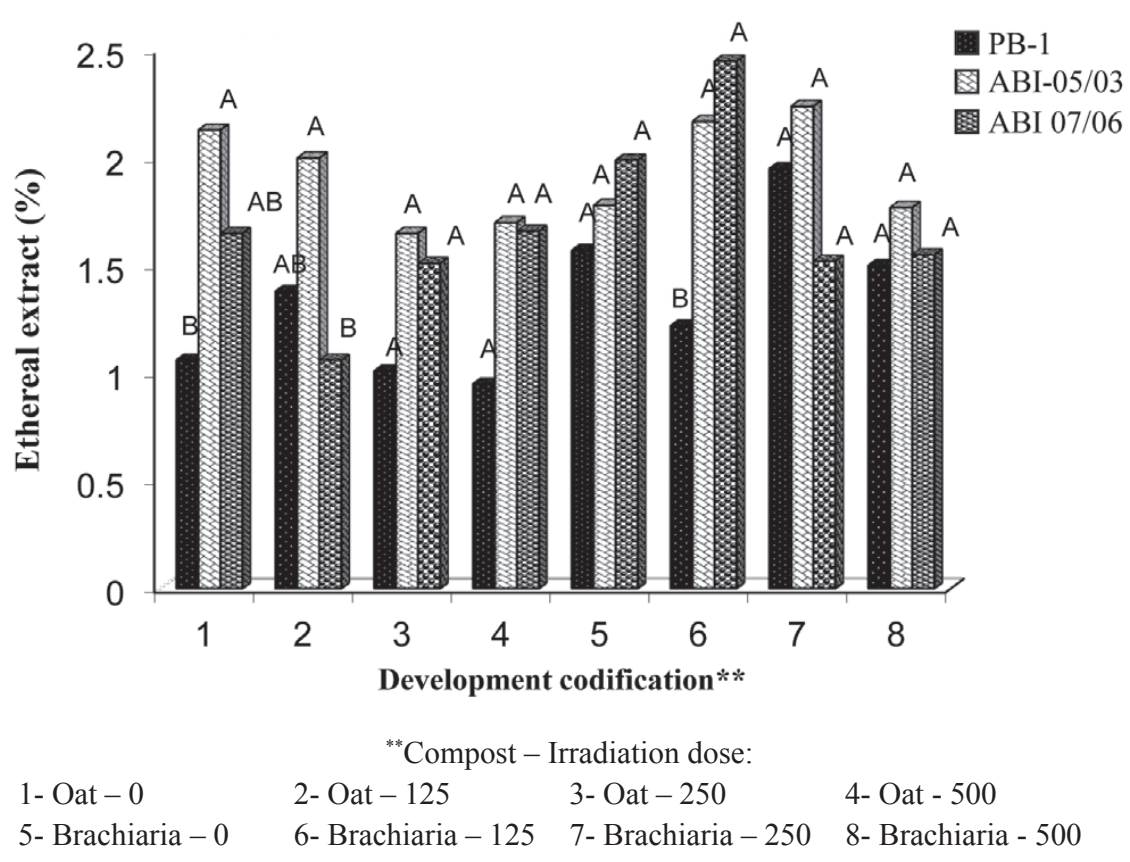

Figure 11 - Comparison of average ethereal extract in mushrooms stored at $4 \pm 1^{\circ} \mathrm{C}$ for 14 days, according to the Agaricus bisporus strain. Averages followed by same letters within each codification are not statistically different from each other (Tukey, 5\%).

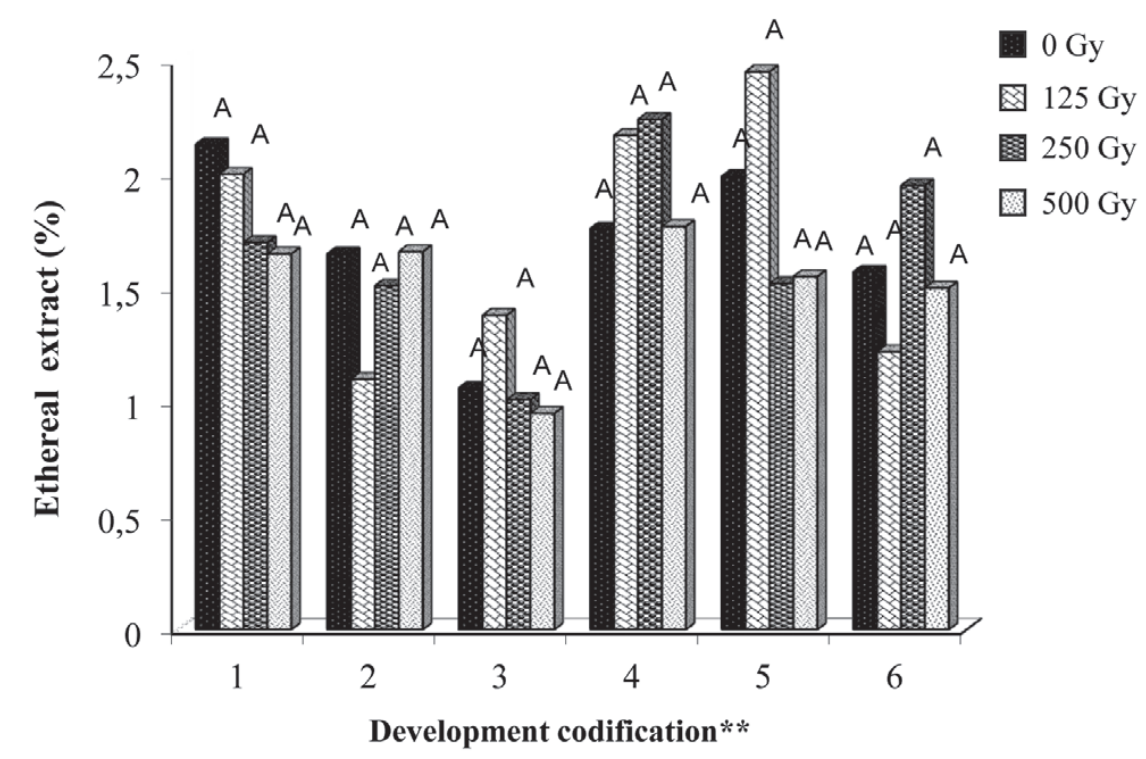

1- Oat - ABI- $05 / 03$
4- Brachiaria - ABI-05/03

** Compost - Agaricus bisporus strain:
2- Oat - ABI-07/06
3- Oat - PB-1
5- Brachiaria - ABI-07/06
6- Brachiaria - PB-1

Figure 12 - Comparison of average ethereal extract in mushrooms stored at $4 \pm 1^{\circ} \mathrm{C}$ for 14 days, according to the irradiation dose. Averages followed by same letters within each codification are not statistically different from each other (Tukey, 5\%). 
Finally, in relation to the protein content on the $14^{\text {th }}$ day of storage, it was found that the PB-1 strain provided the highest average (29.3\%) (Figure 13), which also occurred on the $1^{\text {st }}$ day of storage (Figure 7).

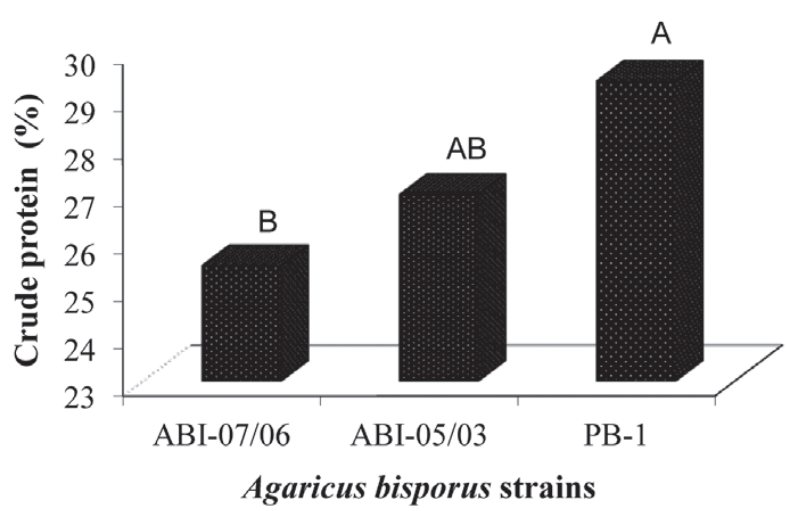

Figure 13 - Comparison of average crude protein present in mushrooms stored at $4 \pm 1^{\circ} \mathrm{C}$ for 14 days, according to the Agaricus bisporus strain. Averages followed by different letters are statistically different from each other (Tukey, $5 \%$ ).

\section{CONCLUSIONS}

All the A. bisporus strains evaluated (ABI-07/06, ABI-05/03 and PB-1) are food with excellent nutritional value due to their chemical composition, because they have high protein and fiber and low ethereal extract contents.

Among the strains analyzed, ABI-07/06 and ABI-05/03 had the highest content of crude fiber and PB-1 showed the highest averages of crude protein.

The chemical characterization of the mushrooms was influenced by the type of compost where they were cultivated, especially the compost based on brachiaria, which provided mushrooms with the highest averages of crude protein and ethereal extract on the $1^{\text {st }}$ day of storage.

Gamma irradiation influenced the chemical composition of the mushrooms, especially the dose of $500 \mathrm{~Gy}$, which provided to highest averages of crude protein and fiber in the mushrooms on the $1^{\text {st }}$ day of storage.

\section{RESUMO}

O efeito de doses de irradiação $(0,125,250$ e 500 Gy) na qualidade nutricional de cogumelos A. bisporus (linhagens ABI-07/06, ABI-05/03 e PB-1) cultivados em compostos à base de palha de aveia (Avena sativa) e braquiária (Brachiaria sp.) foi avaliado. $\mathrm{O}$ delineamento experimental foi em esquema fatorial 4 x 3 x 2 (doses de irradiação x linhagens x compostos), com 24 tratamentos, sendo cada qual constituído de 2 repetições, totalizando 48 unidades experimentais (amostras de cogumelos). As amostras de cogumelos foram irradiadas em irradiador de Cobalto-60, tipo Gammacell 220 e taxa de dose $0,740 \mathrm{kGy} \mathrm{h}^{-1}$, de acordo com os tratamentos propostos. Posteriormente, o controle (não irradiado) e demais tratamentos foram mantidos a $4 \pm 1^{\circ} \mathrm{C}$ e $90 \%$ UR em câmara climatizada para a realização das análises químicas dos cogumelos no $1^{\circ}$ e $14^{\circ}$ dia de armazenamento. Verificou-se que: todas as linhagens de $A$. bisporus avaliadas constituem um alimento com excelente valor nutritivo, pois apresentam alto teor de proteína e fibra bruta, além de conterem baixo teor de extrato etéreo; a caracterização química dos cogumelos foi influenciada pelo tipo de composto em que foram cultivados; a irradiação gama influenciou na composição química dos cogumelos.

Palavras-chave: Agaricus bisporus, produtividade, linhagens, composto, valor nutricional.

\section{REFERENCES}

ANDRADE MCN, ZIED DC, MINHONI MTA AND KoPYTOWSKY FILHO J. 2008. Yield of four Agaricus bisporus strains in three compost formulations and chemical composition analyses of the mushrooms. Braz J Microbiol 39(3): 593-598.

BonONI VLR, CAPELARI M AND TRUFEM SFB. 1995. Cultivo de cogumelos comestíveis. São Paulo: Ícone.

BRENNAN M, LEPORT G AND GORMLEY R. 2000. Post-harvest treatment with citric acid or hydrogen peroxide to extend the shelf life of fresh sliced mushrooms. Food Science and Technology 33(2): 285-289.

Chang ST AND MiLes PG. 1989. Edible mushrooms and their cultivation. Florida: CRC Press.

CHEUNG PCK. 1996. Dietary fiber content and composition of some edible mushroom fruiting bodies and mycelia. $\mathrm{J}$ Agric Food Chem 44(2): 468-471. 
FURLANI RPZ. 2004. Valor nutricional de cogumelos cultivados no Brasil. 88p. Tese (Doutorado em Ciência de Alimentos), Faculdade de Engenharia de alimentos, Universidade Estadual de Campinas (UNICAMP).

FURLANI RPZ AND GODOY HT. 2007. Valor nutricional de cogumelos comestíveis. Ciênc Tecnol Aliment 27(1): 154-157.

KUYPER L, WEINERT IAG AND MC GILL AEJ. 1993. The effect of modified atmosphere packaging and addition of calcium hypochlorite on the atmosphere composition, colour and microbial quality of mushrooms. Food Sci Technol 26(1): 14-20.

Minhoni MTA, Kopytowski Filho J And Andrade MCN. 2005. Cultivo de Agaricus blazei Murrill ss. Heinemann. Botucatu: Fundação de Estudos e Pesquisas Agrícolas e Florestais.
ModA EM. 2008. Aumento da vida útil de cogumelos Pleurotus sajor-caju in natura com aplicação de radiação gama. 105p. Tese (Doutorado em Ciências), Centro de Energia Nuclear na Agricultura, Universidade de São Paulo (USP).

ShibATA CKR AND Demiate IM. 2003. Cultivo e análise da composição química do cogumelo do sol (Agaricus blazei Murril). Publ UEPG Ci Biol Saúde 9(2): 21-32.

SILVA DJ AND QueIroz AC. 2002. Análise de alimentos: métodos químicos e biológicos. Viçosa: UFV. 